\title{
GENETIC VARIANT OF CANINE DISTEMPER VIRUS FROM CLINICAL CASES IN VACCINATED DOGS IN SOUTH AFRICA
}

\author{
WOMA $^{1,2 *}$ T. Y., VAN VUUREN, ${ }^{1}$ M., BOSMAN, ${ }^{1}$ A-M., QUAN ${ }^{1}$ M., OOSTHUIZEN, ${ }^{1}$ \\ M., BWALA ${ }^{2}$ D. G., IBU ${ }^{2}$, J.O., ULARAMU ${ }^{2}$, H.G and SHAMAKI ${ }^{2}$ D., \\ ${ }^{1}$ Department of Veterinary Tropical Diseases, Faculty of Veterinary Science, University of \\ Pretoria, Private Bag X04 Onderstepoort 0110, South Africa.
}

${ }^{2}$ Viral Research Division, National Veterinary Research Institute, P.M.B 01 Vom 930001, Nigeria.

* Corresponding Author: womaty@yahoo.com; Tel: +2348036 895084

\section{SUMMARY}

Canine distemper virus (CDV) is a highly contagious viral pathogen of worldwide distribution that can cause lethal disease in domestic dogs and other members of the family Canidae. Genetic diversity is found among reference strains and isolates of CDV, mainly in the haemagglutinin (H) protein, and this may be associated with the increasing incidence of distemper in dogs. CDV was isolated in Vero cells expressing canine signalling lymphocyte activation molecule (Vero.DogSLAM) from peripheral blood mononuclear cells and spleen of clinically diseased, previously vaccinated South African dogs. Direct fluorescence antibody test and electronmicroscopy were used to confirm the isolation procedure. Subsequently, RT-PCR was performed on the cell culture isolates, the amplified products were purified and the complete $H$ gene was sequenced and phylogenetically analysed. The $H$ gene of vaccines in use in South Africa was also sequenced and comparative analyses performed. However, the sequences obtained from the sick dogs showed $100 \%$ nucleotide identity and was different to that found in virus strains used in vaccines and in isolates reported from other parts of the world in GenBank. The results suggest that a novel CDV lineage may be present in South Africa and we conclude that a recent reversion of vaccine virus to virulence was not the cause of the clinical signs seen in dogs with a previous history of vaccination.

Keywords: CDV; Vaccinated dogs; Genetic diversity; South Africa.

\section{INTRODUCTION}

Canine distemper is an acute or subacute, highly contagious disease with signs of generalized infection, respiratory disease, foot pad hyperkeratosis, central nervous system disturbance or a combination of these (Appel and Summers, 1999). Distemper affects wild and domestic Canidae as well as many other species of carnivores (Appel, 1987). The aetiological agent is canine distemper virus (CDV) which belongs to the genus Morbillivirus within the family Paramyxoviridae. CDV contains two glycoproteins; haemagglutinin (the attachment protein) and a fusion protein, which are the major target antigens for the host immune system (Murphy et al., 1999). The introduction of the live modified CDV vaccines in the 1950s and their extensive use has greatly helped to keep the disease under control (Chappuis, 1995). Notwithstanding, the incidence of 
CDV-related disease in canine population throughout the world seems to have increased in the last decades and several episodes of CDV disease in vaccinated animals have been reported (BlixenkronMoller et al., 1993; Decaro et al., 2004; Gemma et al., 1996; Kai et al., 1993; Scagliarini et al., 2003)

Sequence analysis of CDV strains identified in different geographical settings and from various animal species has revealed that the $\mathrm{H}$ gene/glycoprotein of CDV undergoes a genetic/antigenic drift, according to geographic patterns related to the location of the circulating strains (Bolt et al., 1997; Haas et al., 1999; Iwatsuki et al., 2000; Martella et al., 2006). Herewith, we describe the genetic characterization of canine distemper viruses detected from naturally infected but previously vaccinated dogs in South Africa.

\section{MATERIALS AND METHODS}

\section{Viruses and clinical specimens}

Five CDV strains were sequenced in this study. The CDV-positive cases were identified by screening animals affected with neurological signs, enteritis, or respiratory distress and with a prior history of CDV vaccination. These samples were submitted by animal hospitals and shelters in various parts of Pretoria during 2007. Specimens obtained from living dogs were limited to blood in heparin-containing tubes and spleen from dogs that were euthanized or died with signs of canine distemper. Peripheral blood mononuclear cells (PBMCs) were extracted from the blood samples as previously described (Woma and van Vuuren, 2009), while necropsy tissues were processed on receipt as described by Seki et al., (2003). Each processed specimen was individually inoculated at a volume of $0.5 \mathrm{ml}$ into a $25 \mathrm{~cm}^{2}$ plastic tissue culture flask containing a sub- confluent monolayer of Vero.DogSLAM cells (Woma and van Vuuren, 2009).

Reverse transcription, PCR amplification and Sequencing

Reverse transcription and PCR amplification of the $\mathrm{H}$ gene of CDV was achieved as previously described (Woma et al., 2010). Total RNA was obtained from $200 \mu \mathrm{l}$ of supernatants of infected cells and 5 commercial CDV vaccines $(200 \mu \mathrm{l})$, used in South Africa with the aid of the RNeasy mini kit (Qiagen $®$ ) according to the manufacturer's instructions. The vaccines are not produced in South Africa and different strains are employed for their production. They were initially diluted as prescribed by the manufacturers for injection in dogs.

The amplified PCR products were purified using a QIA quick ${ }^{\circledR}$ PCR purification kit (Qiagen ${ }^{\circledR}$, Southern Cross Biotechnology) according to the manufacturer's instructions. Purified products were directly sequenced with a Big Dye ${ }^{\circledR}$ Terminator v.3.1 cycle sequencing kit (AppliedBiosystems) according to the manufacturer's instructions. The internal $\mathrm{H}$ gene sequence primers were P2F, P3R, P5R, CDV-HS1, CDV-HforD and CDV-Hr2 (Table II) (Lan et al., 2006; Pardo et al., 2005). Precipitation of extension products was by the ethanol precipitation protocol of AppliedBiosystems ${ }^{\circledR}$. Sequence trace files were electrophoresed using the SpectruMedix Genetics analysis system SCE 2410 of Inqaba Biotech (South Africa) and the ABI 3130XL Genetic analyser of the Genetics Laboratory, Equine Research Centre, Faculty of Veterinary Science, University of Pretoria.

Phylogenetic analyses

Sequence data of the full length $\mathrm{H}$ gene were assembled and edited to a total length of $1824 \mathrm{bp}$ using GAP 4 of the 
Staden package (Version 1.6.0 for Windows). The open reading frames of the assembled sequences were aligned with sequences of other $\mathrm{H}$ genes collected from different parts of the world and available in GenBank using MAFFT (Katoh et al., 2002; 2005). The nucleotide sequences were translated into amino acids using the tranalign programme in EMBOSS (Rice et al., 2000).

A transversional model with a proportion of invariable sites and a gamma-shaped distribution of rates across sites $(\mathrm{TVM}+\mathrm{I}+\Gamma)$ substitution model determined by Modeltest v3.7 (Posada and Crandall, 1998), PAUP* v4b10 (Swofford, 2003) and MrBayes v3.1.1 (Ronquist and Huelsenbeck, 2003; Huelsenbeck and Ronquist, 2001) were used to explore distance (Neighbourjoining) and character (Bayesian, Maximum likelihood) based phylogenetic methods of the nucleotide sequences. The consensus trees were edited in MEGA v4 (Kumar et al., 1994; Tamura et al., 2007). The phocine distemper virus (PDV) with GenBank accession number AF479277 was indicated as outgroup in all 3 of the analysis types.

\section{Nucleotide Sequence Accession Numbers}

The nucleotide sequence accession numbers in the GenBank database of $\mathrm{H}$ gene sequences of the isolates from dogs in South Africa and that of vaccine strains available in South Africa are listed in Table I. The nucleotide sequence accession numbers in the GenBank database of $\mathrm{H}$ gene sequences of the reference strains used in this study are: Onderstepoort (AF378705), Convac (Z35493), Snyder Hill (AF259552) and A75/17 (AF164967).

\section{RESULTS}

The cytopathic effects of giant multinucleated syncytium formation and detachment of cells was observed. The presence of CDV was confirmed with a direct fluorescent antibody test and electronmicroscopy as described earlier (Woma and van Vuuren, 2009). For the purpose of comparison, $5 \mathrm{CDV}$ vaccines in use in South Africa were also obtained and the RNA extracted. The profiles of these field CDV strains and that of the vaccines in use in South Africa are summarized in table I. The RT-PCRs performed according to conditions described above resulted in amplicons of the expected size of 2100 bp (Figures 2 and 3) using published primer pairs (Table II) (Lan et al., 2006) with minor modifications. The determined nucleotide sequences of the amplicons were deposited into GenBank under the ascension numbers shown in Table I (Woma et al., 2010).

The national center for biotechnology information basic alignment search tool (NCBI BLAST) was optimized for highly similar sequences (megablast) and the South African isolates showed 95\% maximum identity to a Hungarian strain (GenBank accession no EF095750), an isolates from a Greenlandic dog (Z47760), isolate from a Chinese lesser panda (AF178039), a German dog isolate (X85000), the wild-type strain A75/17 (AF164967) and a United States ferret strain 5804 (AY386315). However, sequences from 4 of the commercial vaccines (A, B, C, and $\mathrm{E}$ ) retailed in South Africa showed $98-99 \%$ maximum identity to vaccine strain (AB212966), the Onderstepoort vaccine strain (AF378705), the Lederle vaccine strain (DQ903854) and the Convac vaccine strain (Z35493). Unexpectedly, one of the commercial vaccine (D) showed $99 \%$ maximum identity to the Hungarian strain (EF095750) and the Chinese lesser panda isolate (AF178039). The sequenced genome fragments from each of the field isolates were translated, resulting in 607 amino acid (aa) long polypeptides, representing the complete sequences of the $\mathrm{H}$ protein. However, 
only sequences of commercial vaccines D and $\mathrm{C}$ yielded 607 amino acids. Vaccines A, B and E had only 604 amino acids like the Onderstepoort and some other earlier vaccine strains available in GenBank. In the neighbour joining tree (Fig. 1), the outgroup (PDV) splits first into the lineage America 1 (bootstrap value $100 \%)$, it then splits into the lineage Asia 2 (bootstrap value 100\%) and a group consisting of the America 2 (bootstrap value 97\%), Europe (bootstrap value $100 \%)$ and Asia 1 (95\%). The tree then finally splits into the Arctic (99\%) and the South African field isolates groups $(100 \%)$.

We sequenced some of these commercial vaccines retailed in South Africa to see if there is any genetic variation as compared to current field isolates. Four (vaccine A, $\mathrm{B}, \mathrm{C}$, and $\mathrm{E}$ ) out of the 5 vaccines sequenced showed $99 \%$ nucleotide identity to each other and to the Onderstepoort CDV and group together with the Onderstepoort strain in lineage America 1. The other one (vaccine D) showed $99 \%$ nucleotide identity to a Hungarian vaccine strain (EF095750) and to a Chinese CDV isolate from lesser panda (AF178039). Vaccine D grouped with other CDV strains in lineage America 2 which has many CDVs of non canine species. These vaccines retailed in South Africa are genetically distinct from the circulating wild-type strains as has been reported in other parts of the world (Calderon et al., 2007; Lan et al., 2006).

Table I. Profiles of the CDV isolates from this study and the vaccines in use in South Africa.

\begin{tabular}{|c|c|c|c|}
\hline Isolate/vaccine & $\begin{array}{l}\text { Breed, sex and age } \\
\text { (in months) }\end{array}$ & Clinical history and findings & $\begin{array}{l}\text { GenBank } \\
\text { accession } \\
\text { numbers }\end{array}$ \\
\hline $5 \mathrm{~L}$ & $\begin{array}{l}\text { Boerboel, female } \\
\text { (12) }\end{array}$ & $\begin{array}{l}\text { Emaciated, cough, oculonasal } \\
\text { discharge, jaw clamping }\end{array}$ & FJ461698 \\
\hline $5 \mathrm{SP}$ & $\begin{array}{l}\text { Cocker Spaniel, } \\
\text { female (12) }\end{array}$ & $\begin{array}{l}\text { Emaciated, cough, oculonasal } \\
\text { discharge, jaw clamping }\end{array}$ & FJ461718 \\
\hline $10 \mathrm{~L}$ & Boerboel, male (6) & Cough, dyspnoea, jaw clamping & FJ461705 \\
\hline $15 \mathrm{SP}$ & Labrador, male (4) & $\begin{array}{l}\text { Depressed, vomiting, bloody } \\
\text { diarrhoea, ocular discharges, } \\
\text { increased lung sounds }\end{array}$ & FJ461706 \\
\hline $25 \mathrm{~L}$ & Yorkie, male (12) & $\begin{array}{l}\text { Depressed, fever, dehydration, } \\
\text { anorexia }\end{array}$ & FJ461712 \\
\hline Vaccine A & Nobivac $®$ DHPPI & - & FJ461701 \\
\hline Vaccine B & Nobivac® PuppyDP & - & FJ461709 \\
\hline Vaccine $\mathrm{C}$ & GalaxyDA $_{2}$ PPV & - & FJ461708 \\
\hline Vaccine D & Vanguard®Plus & - & FJ461702 \\
\hline Vaccine E & Canigen DHPPI & - & FJ461710 \\
\hline
\end{tabular}


Table II. Oligonucleotide primers used for RT-PCR amplification and subsequent nucleotide sequencing of the $\mathrm{H}$ gene*

\begin{tabular}{lllll}
\hline S/No & Primer & Orientation & Sequence $\left(5^{\prime}-3^{\prime}\right)$ & $\begin{array}{l}\text { Nucleotide } \\
\text { Position }\end{array}$ \\
\hline 1 & CDVff1 & Sense & TCGAAATCCTATGTGAGATCACT & $6897-6919$ \\
2 & CDVHS2 & Antisense & ATGCTGGAGATGGTTTAATTCAATCG & $8994-8969$ \\
3 & CDVHS1 & Sense & AACTTAGGGCTCAGGTAGTCC & $7054-7074$ \\
4 & CDVHforD & Sense & GACACTGGCTTCCTTGTGTGTAG & $7948-7970$ \\
5 & CDVHr2 & Antisense & GTTCTTCTTGTTTCTCAGAGG & $8198-8178$ \\
6 & CDVP2F & Sense & ACTTCCGCGATCTCCACT & $7372-7389$ \\
7 & CDVP3R & Antisense & ACACTCCGTCTGAGATAGC & $7760-7742$ \\
8 & CDVP5R & Antisense & GTGAACTGGTCTCCTCTA & $8395-8378$ \\
\hline
\end{tabular}

*Primers were used after Lan et al., 2006 and Pardo et al., 2005.

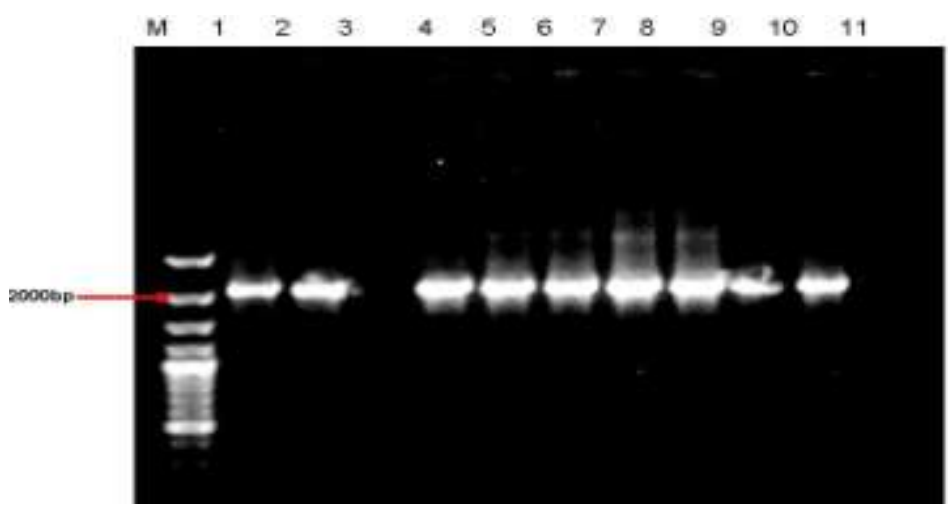

Fig.2. RT-PCR amplification of the $2100 \mathrm{bp}$ complete $\mathrm{H}$ gene of CDV. M, marker (O'Gene Ruler TM 100 bp DNA ladder Plus, Fermentas Life Sciences); lane 1, 2, 9 \& 10, positive clinical specimens used as positive controls for vaccines RT-PCR; lane 3, ultra sterile water used as template RNA; lane 11, Vero.DogSLAM also used as template RNA ( both water and Vero.DogSLAM were used as negative controls). 


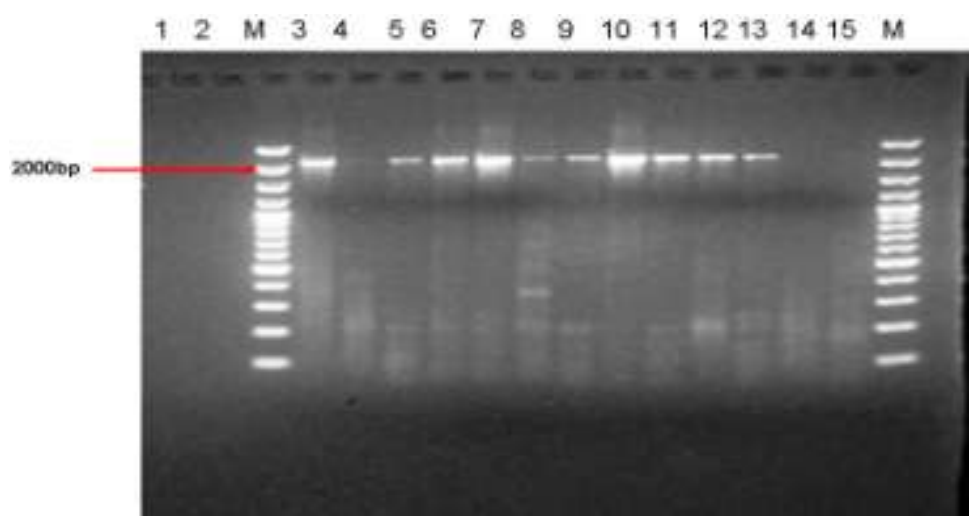

Fig. 3. RT-PCR amplification of the 2100 bp complete $H$ gene of CDV. M, marker (O'Gene Ruler ${ }^{\text {TM }} 100$ bp DNA ladder Plus, Fermentas Life Sciences); lane 1 and 2, ultra sterile water and Vero.DogSLAM used as negative controls respectively. Lane 3, vaccine used as positive control for specimens RT-PCR. Lane $4-13$, positive clinical specimens. Lane 14-15, negative clinical specimens.

\section{DISCUSSION}

The five CDV positive dogs examined in this study had history of CDV vaccination. An unusual CDV lineage was detected in these dogs and phylogenetic analysis of the $\mathrm{H}$ protein sequence of the vaccines in use in South Africa showed that the field strains from this study are genetically distinct from vaccine viruses and other CDV lineages circulating in other parts of the world.

Outbreaks of canine distemper have been reported among vaccinated dogs (Harder et al., 1996; Harder and Osterhaus, 1997; Liermann et al., 1998; MombergJorgensen, 1951; Ott et al., 1957; SimonMartinez et al., 2007). Morbillivirus vaccination failures have also been reported (Blixenkrone-Moller et al., 1993). Clusters of clinical outbreaks have been recorded among human populations with documented measles vaccination coverage of more than $90 \%$ (Gustafson $e t$ al., 1987). Assuming that quality, handling and administration of the vaccines were appropriate in the present cases of vaccination failure, an extraordinarily high infection pressure and immune dysfunctions of the individuals, which may be inherent or due to stress or interference with other current infections at the time of vaccination or at the time of natural exposure, could be important factors responsible for lack of protection against severe clinical disease. It is possible that part of the apparent immunization failures in properly vaccinated dogs may indicate changes in the biological properties of the current field viruses (Blixenkrone-Moller et al.,1993).

Vaccination with modified live vaccine was performed in the cases obtained in this study. Importantly, the CDV strains detected in these clinical cases were genetically distinct from known vaccine strains, as has been demonstrated in previous studies of other CDV positive cases with history of CDV vaccination (Bolt et al., 1997; Calderon et al., 2007; Haas et al., 1999; Iwatsuki et al., 2000; Lednicky et al., 2004; Maes et al., 2003; Martella et al., 2006). These observations 
suggest that a recent reversion of vaccine virus to virulence was not likely to be the cause of the clinical CDV disease seen in dogs for which vaccine had been recently used. The possibility was considered that vaccine failed to have the intended result due to either existing maternal immunity, vaccine failures or the emergence of new strains that are divergent enough to evade immune protection elicited by the vaccines used (Pardo et al., 2007). Thus, renewed efforts may be required by vaccine manufacturers to ensure adequate protection following immunization of dogs against CDV. More studies on genetic characterization will be required to evaluate the efficacies of current CDV vaccines and develop new vaccines against emergence of novel CDV strains. A thorough characterization of the genetic diversity of CDVs can improve our understanding of its emergence, epidemiology, and aid development of new vaccines and diagnostic tests.

There are other distemper vaccines in the global market but the most frequently used products in South Africa are manufactured by Fort Dodge, Pfizer, Intervet, Merial and Virbac. However, it is hoped that the effectiveness of the currently employed vaccines is not partially compromised by the extent of genetic variation observed since $\mathrm{CDV}$ is a monotypic virus as defined by polyclonal antisera.

For the purpose of this phylogenetic analysis, we used the Onderstepoort strain (GenBank accession no AF378705), the Convac strain (Z35493), the Synder Hill strain (AF 259552) and the A75/17 strain (AF164967) as references. The Onderstepoort CDV was derived from the so called Green's distemperoid virus (Green \& Carlson, 1945) which had been isolated from a natural distemper case and serially passaged in ferrets. The ferret-passaged virus was then adapted to chicken eggs and passaged in this system numerous times, after which it was called Onderstepoort-CDV (Haig, 1956). Onderstepoort-CDV is considered to be completely apathogenic and is used in vaccines(Stettler et al., 1997). The Convac strain is also used as a vaccine strain but details on its origin is scanty. The Synder Hill strain is also used for vaccine production. Snyder Hill CDV was isolated from a natural case of distemper and has been serially passaged through direct intracerebral inoculation in dogs (Stettler et al., 1997). Several features of experimental Synder HillCDV infection are similar to the wild type CDV infection (Stettler et al., 1997). The A75/17 CDV is regarded as the virulent prototype of field $\mathrm{CDV}$ isolates. A75/17 is a virulent wild strain isolated from a dog with spontaneous distemper. Under experimental conditions, this virus causes a demyelinating disease and persistent infection of the CNS as seen in natural distemper (Appel, 1969). Current South African field isolates examined in this study did not cluster with the Onderstepoort strain in lineage America 1 but however, showed about 95\% nucleotide identity to the A75/17 strain on NCBI BLAST. Considering the more than 60-year interval between the isolation of the Onderstepoort strain and our present field isolates, such far genetic relationship is not unexpected.

In conclusion, the CDV positive dogs with a history of vaccination were infected with wild-type CDV having a genetic relationship far from the vaccine strain, and showed no evidence of reversion to virulence of vaccine virus.The more commonly reported mutations are in the genes coding for the hemaglutinin/attachment protein $\mathrm{H}$, the fusion protein $\mathrm{F}$ and the nucleocapsid protein N (Mochizuki et al., 1999). Future work should be focused on the study of a greater number of clinical 
samples from vaccinated and nonvaccinated dogs where all the three genes $(\mathrm{H}, \mathrm{F}$, and $\mathrm{N})$ should be analysed. A hemi-nested PCR should be used to enable detailed genotyping of current African lineage strains to really differentiate it from other established lineages. Further study is also needed to generate information regarding crossneutralization (vaccine matching), as well as the immunological and biological characterization of South African canine distemper viruses. To address the issue of whether there is emergence of new strains that differ antigenically from vaccine strains and thus evading immune protection elicited by the vaccines used, research in neutralization activities amongst vaccine virus and new isolates; information of the antibodies of dogs after vaccination and research with experimental vaccinated dogs is recommended.

\section{REFERENCES}

APPEL, M. J. G. (1969): Pathogenesis of canine distemper. Am. J. Vet. Res. 30, 1167-1182.

APPEL, M.,(1987): Canine distemper virus. In: Appel M J (Ed.), Virus infections of Carnivores. Elsevier Science Publishers B.V., Amsterdam, The Netherlands, pp $133-159$.

APPEL, M. J. G. and SUMMERS, B. A. (1999): Canine distemper: Current status. In: Recent advances in canine infectious diseases. Edited by L.E Carmihael. www.ivis.org/publications/library. Accessed on 21 may 2008.

BLIXENKRONE-MOLLER, M., SVANSSON, V., HAVE, P., ORVELL, C., APPEL, M., RODE PEDERSEN, I., HENRIK DIETZ, H. and HENRIKSEN, P. (1993): Studies on manifestations of canine distemper virus infection in an urban dog population. Vet. Microbiol 37, 163-173.

BOLT, G., JENSEN, T. D., GOTTSCHALCK, E., ARCTANDER, P., APPEL, M. J. G., BUCKLAND, R. and BLIXENKRONE-MOLLER, $\mathrm{M}$. (1997): Genetic diversity of the attachment $(\mathrm{H})$ protein gene of current field isolates of canine distemper virus. J. Gen. Virol 78, 367-372.

CALDERON, M. G., REMORINI, P., PERIOLO, O., IGLESIAS, M., MATTION, N. and LA TORRE, J. (2007): Detection by RT-PCR and genetic characterization of canine distemper virus from vaccinated and non-vaccinated dogs in Argentina 23. Vet. Microbiol 125, 341-349.

CHAPPUIS, G. (1995): Control of canine distemper. Vet. Microbiol 44, 351-358.

DECARO, N., CAMERO, M., GRECO, G., ZIZZO, N., TINELLI, A., CAMPOLO, M., PRATELLI, A. and BUONAVOGLIA, C. (2004): Canine distemper and related diseases: report of a severe outbreak in a kennel. New Microbiol 27, 177-182.

GEMMA, T., IWATSUKI, K., SHIN, Y., YOSHIDA, E., KAI, C. and MIKAMI, T. (1996): Serological analysis of canine distemper virus using an immunocapture enzyme linked immunosorbent assay. $J$. Vet. Med. Sci. 58, 791-794.

GREEN, R. G. and CARLSON, W. E. (1945): The immunization of foxes and dogs to distemper with ferret-passage virus. J.Am. Vet. Med. Ass. 107, 131-142. 
GUSTAFSON, T. L., LIEVENS, A. W., BRUNELL, P. A., MOELENBERG, R. G., BUTTERY, C. annd SCHULSTER, L. M. (1987): Measles outbreak in a fully immunized secondary school population. New Engl. J. Med. 316, 771-774.

HAAS, L., LIERMANN, H., HARDER, T. C., BARRETT, T., LOCHELT, M., VON MESSLING, V., BAUMGARTNER, W. and GREISER-WILKE， I. (1999): Analysis of the $\mathrm{H}$ gene, the central untranslated region and the proximal coding part of the $\mathrm{F}$ gene of wild-type and vaccine canine distemper viruses. Vet. Microbiol. 69, 15-18.

HAIG, D. A. (1956): Canine distemperimmunisation with avianised virus. Onderst. J. Vet. Res. 27, 1953.

HARDER, T. C., KENTER, M., VOS, H., SIEBELINK, K., HUISMAN, W., AMERONGEN, G., IRVELL, C., BARRETT, T., APPEL, M. J. G. and OSTERHAUS, A. D. M. E. (1996): Canine distemper virus from diseased large felids: biological properties and phylogenetic relationships. $J$. Gen. Virol. 77, 397-405.

HARDER, T. C. and OSTERHAUS, A. D. M. E. (1997): Canine distemper virus -- A morbillivirus in search of new hosts? Trends in Microbiol. 5, 120-124.

HUELSENBECK, J. P. and RONQUIST, F. (2001): MRBAYES: Bayesian inference of phylogenetic trees. Bioinformatics 17, 754-755.
IWATSUKI, K., TOKIYOSHI, S., HIRAYAMA, N., NAKAMURA, K., OHASHI, K., WAKASA, C., MIKAMI, T. and KAI, C. (2000): Antigenic differences in the $\mathrm{H}$ proteins of canine distemper viruses. Vet. Microbiol. 71, 281286.

KATOH, K., KUMA, K., TOH, H. and MIYATA, T. (2005): MAFFT version 5: improvement in accuracy of multiple sequence alignment. Nucleic Acids Res. 33, 511-518.

KATOH, K., MISAWA, K., KUMA, K. and MIYATA, T. (2002): MAFFT: a novel method for rapid multiple sequence alignment based on fast Fourier transform. Nucleic Acids Res. 30, 3059-3066.

KAI, C., OCHIKUBO, F., OKITA, M., LINUMA T, MIKAMI, T., KOBNNE $\mathrm{F}$ and YAMANOUCHI, K. (1993): Use of $\mathrm{B} 95 \mathrm{a}$ cells for isolation of canine distemper virus from clinical cases. J. Vet. Med. Sci. 55, 1067-1070.

KUMAR, S., TAMURA, K. and NEI, M. (1994): MEGA: Molecular Evolutionary Genetics Analysis software for microcomputers. Comput. Appl. Biosci. 10, 189191.

LAN, N. T., YAMAGUCHI, R., INOMATA, A., FURUYA, Y., UCHIDA, K., SUGANO, S. and TATEYAMA, S. (2006): Comparative analyses of canine distemper viral isolates from clinical cases of canine distemper in vaccinated dogs. Vet. Microbiol. 115, 32-42.

LEDNICKY, J. A., DUBACH, J., KINSEL, M. J., MEEHAN, T. P., 
BOCCHETTA,

M., HUNGERFORD, L. L., SARICH, N. A., WITEKI, K. E., BRAID, M. D., PEDRAK, C. and HOUDE, C. M. (2004): Genetically distant american canine distemper virus lineages have recently caused epizootics with some what different characteristics in raccoons living aroun a large suburban zoo in the USA. Virol. J. 1.

LIERMANN, H., HARDER, T. C., LOCHELT, M., VON MESSLING, $\quad \mathrm{V}$., BAUMGAERTNER, W., MOENNIG, V. and HAAS, L. (1998): Genetic analysis of the central untranslated genome region and the proximal coding part of the $F$ gene of wild-type and vaccine canine distemper morbilliviruses. Virus Genes 17, 259-270.

MAES, R. K., WISE, A. G., FITZGERALD, S. D., RAMUDO, A., KLINE, J., VILNIS, A. and BENSON, C. (2003): A canine distemper outbreak in Alaska: diagnosis and strain characterization using sequence analysis. J. Vet. Diag. Invest. 15, 213-220.

MARTELLA, V., CIRONE, F., ELIA, G., LORUSSO, E., DECARO, N., CAMPOLO, M., DESARIO, C., LUCENTE, M. S., BELLACIO, A. L., BLIXENKRONEMOLLER, M., CARMICHAEL, L. E. and BUONAVOGLIA (2006): Heterogeneity within the hemagglutinin genes of canine distemper virus (CDV) strains detected in Italy. Vet. Microbiol. 116, 301-309.

MOCHIZUKI, M., HASHIMOTO, M., HAGIWARA, S., YOSHIDA, Y. and ISHIGURO, S. (1999): Genotypes of canine distemper virus determined by analysis of the hemagglutinin genes of recent isolates from dogs in Japan. J. Clin. Microbiol. 37, 2936-2942.

MOMBERG-JORGENSEN, H. C. (1951): Studies of distemper. 3. Effect of diet on the result of vaccinations. Nordisk Veterinaermedicin 3, 675-680.

MURPHY, F.A, GIBBS, E.P.J, HORZINEK, M.C., and STUDDERT, M.J. (1999): Veterinary Virology, $3^{\text {rd }}$ ed. Academic Press, San Diego, CA, pp $411-428$.

OTT, R. L., GORHAM, J. R. and GUTIERREZ， J. C. (1957): Distemper in dogs. II. The response to vaccination. Am. J.Vet. Res. 18, 375-381.

PARDO, I. D. R., JOHNSON, G. C. and KLEIBOEKER， S. B. (2005): Phylogenetic characterization of canine distemper viruses detected in naturally infected dogs in North America. J. Clin. Microbiol. 43, 5009-5017.

PARDO, M. C., TANNER, P., BAUMAN, J., SILVER, K. and FISCHER, L. (2007): Immunization of Puppies in the Presence of Maternally Derived Antibodies Against Canine Distemper Virus. J. Comp. Pathol. 137, S72-S75.

POSADA, D. and CRANDALL, K. A. (1998): MODELTEST: testing the model of DNA substitution. Bioinformatics 14, 817-818.

RICE, P., LONGDEN, I. and BLEASBY, A. (2000): EMBOSS: the European Molecular Biology 
open software suite. Trends in Genetics 16, 276-277.

RONQUIST, F. and HUELSENBECK, J. P. (2003): MrBayes 3: Bayesian phylogenetic inference under mixed models. Bioinformatics 19, 1572-1574.

SCAGLIARINI, A., BATTILANI, M., CIULLI, S., PROSPERI, S. and MORANTI, L. (2003): Molecular analysis of the NP gene of Italian CDV isolates. Vet. Res. Comm. 27, 355-357.

SEKI, F., ONO, N., YAMAGUCHI, R. and YANAGI, Y. (2003): Efficient isolation of wild strains of canine distemper virus in Vero cells expressing canine SLAM (CD150) and their adaptability to marmoset B95a cells. J. Virol. 77, 9943-9950.

SIMON-MARTINEZ, J., ULLOAARVIZU, R., SORIANO, V. E. and FAJARDO, R. (2007): Identification of a genetic variant of canine distemper virus from clinical cases in two vaccinated dogs in Mexico. Vet. J. 175, 423426.

STETTLER, M., BECK, K., WAGNER, A., VANDEVELDE, M. and ZURBRIGGEN, A. (1997):
Determinants of persistence in canine distemper viruses. Vet. Microbiol. 57, 83-93.

SWOFFORD, D. L. (2003): PAUP*. Phylogenetic Analysis Using Parsimony (*and Other Methods). Version 4b10. Sunderland, Massachusetts: Sinauer Associates.

TAMURA, K., DUDLEY, J., NEI, M. and KUMAR, S. (2007): MEGA4: Molecular Evolutionary Genetics Analysis (MEGA) Software Version 4.0. Molecular Biology \& Evolution 24, 15961599

WOMA T.Y and VAN VUUREN M. (2009): Isolation of canine distemper viruses from domestic dogs in South Africa using Vero.DogSLAM cells and its application to diagnosis. Afri. J. Microbiol. Res. 3 (3), $111-118$.

WOMA T. Y, VAN VUUREN M., BOSMAN A-M., QUAN M., and OOSTHUIZEN M., (2010): Phylogenetic analysis of the haemagglutinin gene of current wild-type canine distemper viruses from South Africa: Lineage Africa. Vet. Microbiol., 143:126-132 
Figure1.

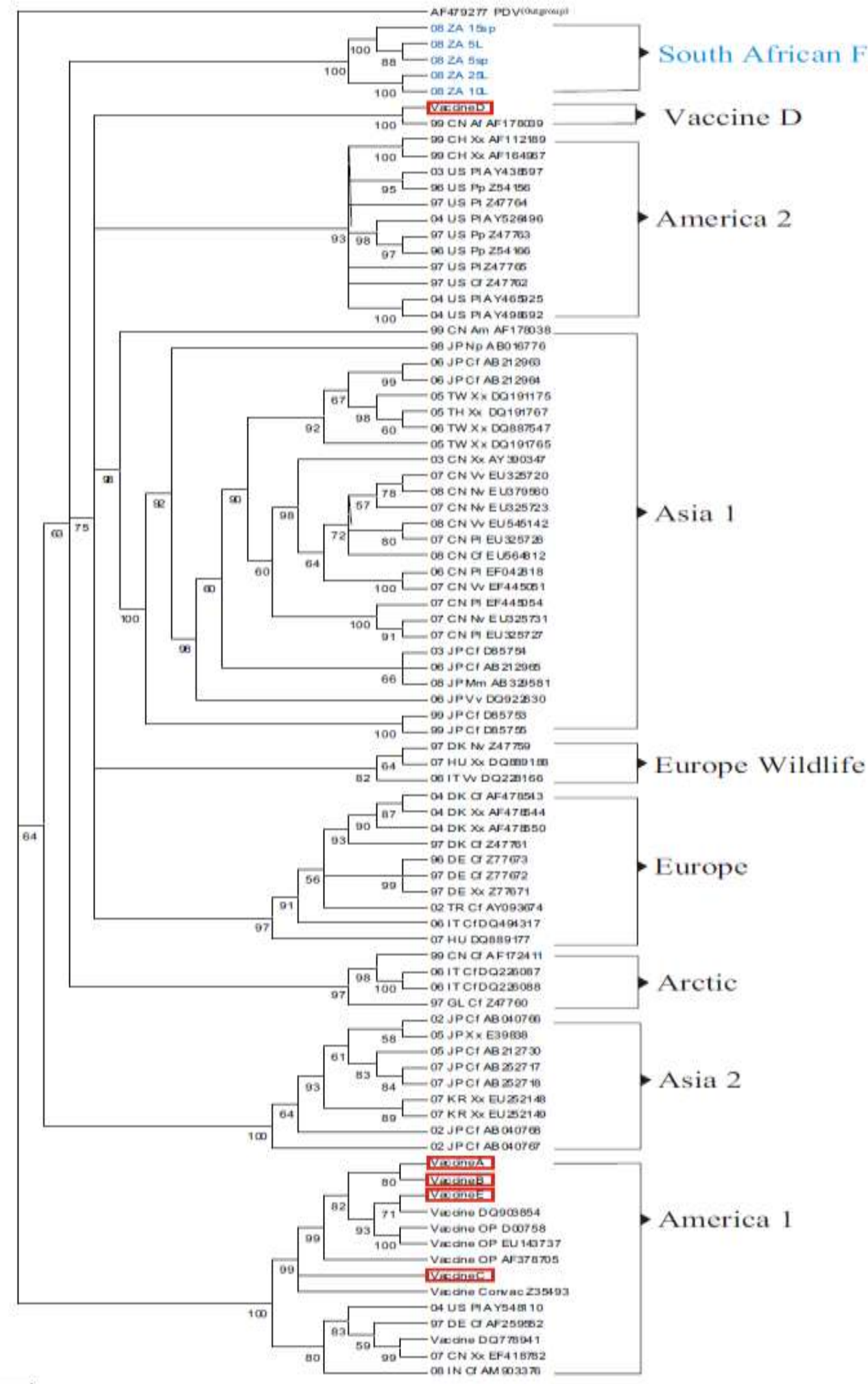

